\title{
The Relationship of Hadith Style to the Social Society of the Nusantara: A Study on Qami 'Al-Tughyan by Nawawi Al-Bantani
}

\author{
Perdana Putra Pangestu \\ Universitas Islam Negeri Sunan Kalijaga Yogyakarta, Indonesia \\ Email: perdanaputrapangestu@gmail.com
}

\begin{abstract}
One of the nusantara scholars with famous work inscriptions is Nawawi alBantani. These works are recorded in a multidisciplinary scope, one of which is Qami 'al-Tughyan. The significance of this research lies in the influence of environmental factors of Nawawi in the nusantara which have an influence on the style of writing, especially in the field of hadith. This study aims to reveal the facts of causality with the orientation of the literature analysis surrounding Nawawi's notes in compiling the Qami' alTughyan. The author will take an inductive qualitative approach by conducting a literature review through related literatures, derived from the object variables in the first ten sections (syu'bah) of the book Qami 'alTughyan. Then, the data will be explored in order to produce comprehensive and optimal research results. This research proves that the work recording model used by Nawawi is a causal representation of the situation in the nusantara, especially with regard to the practice of imperialism towards the indigenous people.
\end{abstract}

Keywords: Nawawi al-Bantani, Qami' al-Tughyan, Hadith Nusantara

\begin{abstract}
Abstrak
Dalam bilik khazanah tokoh nusantara, masyhur dikenal seorang ulama bernama Nawawi al-Bantani dengan torehan emas karya-karyanya, salah satunya adalah Qami' al-Tughyan. Tujuan visioner serta faktor lingkungan Nawawi di tanah nusantara membawa pengaruh terhadap corak kepenulisannya di bidang hadis. Asumsi tersebut muncul seiring dengan cakupan persoalan tentang bagaimana relasi antara keadaan sosial kemasyarakatan riil saat itu, dapat bersinggungan dan menimbulkan keterkaitan dengan karya-karyanya, utamanya dalam corak metodologi hadis. Penulis merasa perlu untuk mereduksi konsep metodologis Qami' al-Tughyan ke dalam suatu premis yang tersusun, dengan melakukan tinjauan kepustakaan melalui literatur-literatur terkait. Penulis akan menggunakan
\end{abstract}


analisis kualitatif dengan berorientasikan pada telaah pustaka dan fakta sejarah. Kajian ini mengambil variabel objek pada sepuluh bagian pertama (syu'bah) pada kitab Qami' al-Tughyan. Penulis berharap kajian ini akan membawa sumbangsih terhadap khazanah keilmuan Islam, yakni untuk mengetahui pola metodologi hadis dan korelasinya dengan situasi sosial kemasyarakatan nusantara dalam karya Qami' al-Tughyan.

Kata Kunci: Nawawi al-Bantani, Qamial-Tughyan, Hadis Nusantara

\section{Introduction}

The journey of Islamic scholarship in the nusantara has experienced a long dynamic. History has proven that the progress and track records of figures and scholars have written gold ink in it. It is undeniable that the contribution of the thoughts of the nusantara ulama has brought the continuity of Islamic scholarship and its teachings to this day. So that the ulama's thoughts that are expressed in a work or tradition can be studied by future generations. Some of the scholars referred to are Muhammad Nawawi al-Bantani al-Jawi, or commonly referred to as Nawawi al-Bantani. Nawawi al-Bantani is proven to have made contributions to the theological and scientific foundations of Islam in Indonesia. So that his big gait is predicted to be a label as the foundation of Islamic scholarship in the nusantara. This fact is none other than the departure from the fact that Nawawi al-Bantani was a scholar who became a teacher over other ulama in the nusantara. So that the concept of thought and teaching is perpetually passed on to the next generation. (Bizawie, 2015, p. 33)

From the various works that can be accessed until now, Nawawi is considered as a productive writer. Nawawi al-Bantani devotes his thoughts to a variety of works that are contained in various disciplines. Call it the coverage of tafsir, sharia, sufism, fiqh to hadith. Judging from his works aimed at the Islamic scientific generation in the nusantara, this has resulted in hegemony in the pesantren to madrasah's which has made Nawawi al-Bantani's work the main literature in his diniyah teachings. (Niam, 2010, p. 288)

Burhanuddin, et al. in Kajian Kontemporer terhadap Karya Nawawi al-Bantani, describes how the continuity of scientific observations in the works of Nawawi al-Bantani in the category of the contemporary period. More specifically, Burhanuddin narrowed down the momentum of his study of works between 2007 and 2017. He also found a conclusion that various studies based on the work of Nawawi al-Bantani were still fixated on his monumental works. Nawawi al- 
Bantani's products in other disciplines were not well touched by researchers. So that the research conception only touches the macro realm, with minimal touch on the micro aspects. (Burhanuddin, Syamsuddin, and Qudsy 2020) Meanwhile, Muqoddas in Syeikh Nawawi al-Bantani al Jawi Ilmuan Spesialis Ahli Syarah Kitab Kuning, tries to dissect the flow of dynamic patterns in the works of Nawawi al-Bantani. Muqoddas conducted a study by looking at the chronological domain of Nawawi al-Bantani's work and seeing the contents contained in it. He found the conclusion that Nawawi alBantani used a conclusive signaling style predominantly to his works. So he also called Nawawi al-Bantani an expert in the field of syarah yellow books. (Muqoddas, 2014) Meanwhile, Rahman in Nawāwī al Bantānī: An Intellectual Master of the Pesantren Tradition, contributed assumptions about Nawawi al-Bantani's motivating factors when studying. According to him, apart from personal factors as motivation to continue scientific work in Mecca, the ulama of the nusantara were also inseparable from the internal situation in the nusantara at that time. Especially for Nawawi al-Bantani, he was greatly influenced by domestic factors, especially those related to political aspects. This factor is the Diponegoro War which took place in the period 1825-1830, as well as the war against the Dutch colonialists. According to Rahman, these two major events influenced the scientific experience and revolutionary thinking of the natives, especially Nawawi al-Bantani, in contributing to resistance in the theological field. (Rahman, 1996)

In this case, the author will further examine the work of Nawawi al-Bantani entitled Qami 'al-Tughyan' ala Manzumat Syu'ab al-Iman in the hadith perspective and its relation to the scientific texts of the hadith. This motivation is motivated by various reasons. First, the author assumes that the scientific complexity that is mastered by Nawawi will also have an impact on the style of writing in the hadith field. Second, the author also considers that the purpose of composing Qami 'al-Tughyan and Nawawi's environmental factors in the nusantara also had an influence on his writing style in the field of hadith. Thus, the author aims to trace the historical recording model of the Nawawi al-Bantani era, which is represented through his works, especially Qami 'al-Tughyan. The significance of this research will be illustrated in the substance of the arguments offered by Nawawi alBantani in responding to the phenomena that occur. Furthermore, this research is expected to become a new discourse for tracing the 
works of nusantara figures by making comparisons and elaborations of theological-historical paradigms.

To obtain optimal research results, the author uses a qualitative inductive analysis model based on a literature review, or what is known as a research library. The research orientation was taken based on, (1) argumentative analysis, (2) literature reference analysis; (3) Historical review. (Hamzah, 2019, p. 33) Meanwhile, in data collection, the author conducted a review of the book Qami 'alTughyan as well as sorting the readings of the scope of the discussion on the book Qami' al-Tughyan and some supporting literature in the form of hadith works or those involving hadith by Nawawi al-Bantani. References related to the language are excerpts from major sources, scientific books and journals. Then, the data will be analyzed exploratively, which opens the power of optimal interpretation to the desired focus of study.

On the margins of his study, the author focuses on the first ten points of the book Qami 'al-Tughyan. The first ten points referred to are the scope of the language in the book called Syu'bah (branch/ section). The author assumes that the first ten bases in the book Qami 'al-Tughyan represent the hadith methodology used by Nawawi alBantani in strengthening his narrative sharah. Then the author makes a historical reality connection between the social situations of the nusantara, especially in Java, in giving influence to the works of Nawawi al-Bantani in Qami 'al-Tughyan and his other works.

\section{Results and Discussion}

Biography E Intellectual Experience of Nawawi al-Bantani

Nawawi al-Bantani's full name is Abu Abdul Mu'ti Muhammad bin Umar al-Tanara al-Bantani al-Jawi. This name is a collaboration of various works bearing his name. (Muqoddas, 2014, p. 7) However, Nawawi has the real name Muhammad Nawawi and is famously known as Nawawi al-Bantani. Nawawi al-Bantani was born in Tanara, Tirtayasa sub-district, Serang district, Banten Residency in 1815 AD and died in Shi'ib Ali, Mecca (his residence) in $1897 \mathrm{AD}$ at the age of 
84 years. Nawawi al-Bantani is the son of a cleric and leader in Banten named Kiai Umar. Which is through the path of his father, Nawawi alBantani by lineage to Rasulullah SAW. through the Ja'far as Shiddiq. (Mamat Slamet Burhanuddin, 2010, p. 123) In addition to being someone who has a lineage to the Prophet Muhammad. Nawawi alBantani is also a person who holds the title of nobility, namely through the descendants of the Sultan of Banten I, namely Sunyararas. (Mamat S. Burhanuddin et al., 2020, p. 85)

Tracing the early journey of Nawawi al-Bantani's basic Islamic education, he got it from his own father. From the beginning, Kiai Umar had predicted his son to become a scholar. Namely by providing scientific tools (nahwu, șorof), tafsir, fiqh and tauhid. (Siregar, 2007, p. 101) After finishing his basic knowledge, his father handed him over to one of the ulama in Banten, KH Sahal, and then went to Purwakarta to meet $\mathrm{KH}$ Yusuf. As of his knowledge journey at the pesantren took about 6 years. (Amin, 2009, p. 22) Nawawi al-Bantani's educational path does not stop at Purwakarta. This initial experience led him to carry out Islamic scientific research in various countries, namely Egypt, Medina, Syria and Mecca. There Nawawi al-Bantani continued his thirst for knowledge in a multidisciplinary scientific scope. While in Mecca, after he performed the haj pilgrimage, he studied with the Hijaz and ulama who were born in Indonesia. Some of them are Sheikh Akhmad Khatib Sambas (d. 1875 AD), Syekh Abdul Ghani Bima (d. 1270 H), Syekh Ahmad Zaini Dahlan (d. 1886 AD). In addition to being a knowledge attorney from the community, Nawawi alBantani while in Mecca often received a mandate to replace Sheikh Khatib Sambas to become the Grand Imam of the al-Haram Mosque. (Siregar, 2007, p. 102)

According to Siregar, his scientific journey lasted three decades, from 1830 to 1860 . After that, Nawawi al-Bantani continued his service by teaching and writing works. (Siregar, 2007, pp. 102-103) He also became a teacher for students from various countries. Some of his students were KH Asyari Bawean (d. 1921 AD), KH Khalil Bangkalan (d. 1925 AD), KH Hasyim Asyari (w. 1947 AD), KH Asnawi Kudus (d. 
1959 H), KH Tubagus Bakri al-Sampuri (d. 1975 AD). These students who later became the successor to the famous scholars in the country. Nawawi's successful works are also very diverse. The number is up to dozens of books in various scopes of discussion, namely tafsir, fiqh, tasawuf, kalam, tauhid, sirah, morals and hadith. Nawawi's writing work was then massively used as one of the Islamic scientific teaching curricula in various religious education institutions in Indonesia, Malaysia, Thailand, the Philippines and the Middle East. (Mamat S. Burhanuddin et al., 2020, p. 47) In this regard, Nawawi's proficiency in the field of religion, several prestigious titles also bore on his shoulders. Like A'yan Ulama al-Qarn al-Rabi 'Asyar li al-Hijrah; alImam al-Muhaqqiq wa al-Fahhamah al-Mudaqqiq; Imam Ulama alHaramain; Sayyid al-'Ulama al-Hijaz; Bapak Kitab Kuning Indonesia. (A. Arwansyah \& Shah, 2015, p. 75; Mamat Slamet Burhanuddin, 2010, p. 125; Mabrur, 2016, p. 71) These titles are a representation of achievements and role models for present and future Islamic scholars.

Insights Regarding the Book of Qami 'al-Tughyan

The book of Qami 'al-Tughyan etymologically has two words, namely Qami' and al-Tughyan. Qami' has the meaning of directing, controlling, suppressing. Meanwhile, al-Tughyan means disobedience, iniquity. If a short definition is drawn, then this book can be interpreted as a book containing intervening directives so that someone does not fall into the realm of immorality. With the aim that these directions will lead people to the path of truth taught in Islam. (Hidayah, 2014, p. 72) The book Qami 'al-Tughyan is a work in the form of sharah from the book Syu'ab al-Iman by Zainuddin bin Ali bin Ahmad as Syafi'i al-Kusyini al-Fannani al-Malibari (hereinafter referred to as Zainuddin al-Malibari). The book of Syu'ab al-Iman actually comes from Nur al-Din al-'Iji who uses Persian. Then this book was translated into Arabic by Zainuddin al-Malibari, and the book was translated by Nawawi al-Bantani.

In the book Qami 'al-Tughyan, Nawawi explains clearly that this book is exclusively for the next generation in the country. At the level of the literature analysis that the author considers to do, causal 
specifications through the historical records of the writing of this book cannot be found. That is, the author did not find a specific cause for the events behind the writing of the book Qami 'al-Tughyan. However, Muqoddas stated that the works compiled by Nawawi alBantani were entirely dedicated to the continuity of religious education, especially in Indonesia. (Muqoddas, 2014, p. 16) Nawawi alBantani specializes in composing a work which is nothing but to be used by the students. In addition, Nawawi al-Bantani was also present to provide convenience in accessing Islamic scholarship from the scholars, in the form of syarah. This is often reflected in the language style of Nawawi al-Bantani which tends to be friendly with indigenous contexts. (al-Bantani, n.d.-a)

Qami 'al-Tughyan contains the syarah Syu'ab al-Iman which has 26 verses, but Nawawi al-Bantani adds 3 stanzas to this sharah. The additions include 3 stanzas from Nawawi al-Bantani (at the beginning) and 1 from Shaykh Abdul Mun'im (at the end). Thus, the total number of verses in the book of Qami 'al-Tughyan is 30 stanzas. This book has the characteristic of discussing the forms of realization of a servant of his faith. The forms referred to are 77 syu'bah (branches) which are based on 34 verses of the Quran, 54 matn hadiths, sayings of Shahabah, tabi'in and scholars, as well as several stories to wirid. (Huda, 2017, p. 28) The syu'bah in question begins with "Faith in Allah" and ends with "Loving Humans as Loving Yourself". When viewed in a major scope of study, this book is a representation of Muslim hadith no. 51 which reads, (Muslim bin al-Hajjaj, 2010, no. 51)

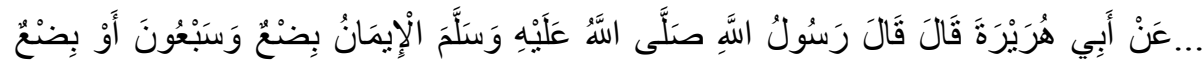

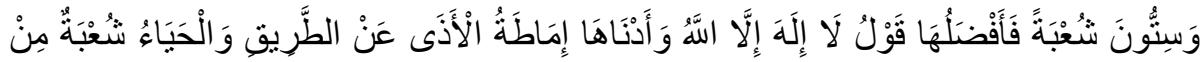

Meaning:" from Abu Hurairah, he said, "Rasulullah SAW. Said: "Faith is seventy-three to seventy-nine, or sixty-three to sixty-nine branches. Foremost is the word, Laa Ilaha Illallah (No god has the right to be 
worshiped but Allah). And the lowest thing is to remove distractions from the road. And shame is part of faith"

\section{Identification of Hadith in the Book of Qami 'al-Tughyan}

From the author's observation of the first ten syu'bah, it can be described in the table below:

\section{Table 1. Ten Syu'bah}

\begin{tabular}{|c|c|c|c|}
\hline Syu'bah & $\begin{array}{l}\text { Citing the Source of } \\
\text { Hadith* }\end{array}$ & $\begin{array}{c}\text { Hadith Recording Category } \\
\text { Not Citing the Source of } \\
\text { Hadith }^{* *}\end{array}$ & $\begin{array}{l}\text { Not Citing } \\
\text { Hadith*** }\end{array}$ \\
\hline 1 & - & $\begin{array}{l}\text { Șahīh al-Bukhāri (no. 6924) and } \\
\text { Șahīh Muslim (no. 20) with } \\
\text { șahīh quality }\end{array}$ & - \\
\hline 2 & $\begin{array}{l}\text { Șahīh al-Bukhāri (no. } \\
\text { 4777) and Ṣahīh } \\
\text { Muslim (no. 5) with } \\
\text { șahīh quality }\end{array}$ & - & - \\
\hline 3 & - & - & There is no hadith \\
\hline 4 & - & - & There is no hadith \\
\hline 5 & - & - & There is no hadith \\
\hline 6 & $\begin{array}{l}\text { Șahīh Muslim (no. 5) } \\
\text { with șahīh quality }\end{array}$ & - & - \\
\hline 7 & $\begin{array}{l}\text { Șahīh al-Bukhāri (no. } \\
\text { 7121) with șahīh quality }\end{array}$ & - & - \\
\hline 8 & $\begin{array}{l}\text { Sahīh Muslim } \quad \text { (no. } \\
\text { 2862) with șahìh } \\
\text { quality }\end{array}$ & $\begin{array}{l}\text { Al-Mundziriy in Targhīb wa at- } \\
\text { Tarhīb (IV/ 291) with } \\
\text { information } \\
\text { or it can be said as șahīh. }\end{array}$ & - \\
\hline 10 & $\begin{array}{l}\text { Șahīh al-Bukhāri (no. } \\
\text { 1379) and Șahīh } \\
\text { Muslim (no. 2866) } \\
\text { with șahīh quality } \\
\text { Șahīh al-Bukhāri (no. } \\
\text { 16) and Șahīh Muslim } \\
\text { (no. 43) with șahīh } \\
\text { quality }\end{array}$ & - & - \\
\hline
\end{tabular}

Note:

* The mention in the book is simple. Then the author completes it with the name of the book and the number of the hadith;

${ }^{* *}$ There is no mention in the book. But the author still completes it with the name of the book and the number of the hadith; 
***There is no hadith quoted.

As the author has mentioned in the steps of the research method, the author takes a sample of the first ten syu'bah in the book Qami 'alTughyan. These first ten syu'bah represent the majority of the authorship of the hadiths of Nawawi al-Bantani in this book. However, in strengthening the database, the author also completes a review of the entire syu'bah and provides several examples of the same cases of syu'bah apart from the first ten syu'bah.

In Syu'bah al-Awwal, namely al-Iman Billah, Nawawi al-Bantani quoted a piece of the hadith from Abu Hurairah, without mentioning the source of the hadith quoted. However, after examining it, this hadith is found in some hadith literature, which the author in this case takes from Șahīh Bukhāri no. 6924 and Șahīh Muslim no. 20 with sahīh quality. (al-Bukhari, 2002, no. 6924; Muslim bin al-Hajjaj, 2010, no. 20) It is different with Syu'bah al-Tsaniy, where Nawawi al-Bantani mentions the source of the narration of hadith. There, Nawawi alBantani mentioned that the pieces of the hadith quoted were taken from șahīhaini (Șahīh Bukhāri and Șahīh Muslim). The term taken from the hadith from șahīhaini is also the same as that in Syu'bah alSabi'ah, Syu'bah al-Tasi'ah and Syu'bah al-'Asyiroh.

Whereas in Syu'bah al-Tsalisah to Syu'bah al-Khamis, Nawawi alBantani did not perform hadith recitation to complete his sharah. Instead, it only includes the verse from the al-Quran that underlies the basics of the syu'bah studied with the sentence qāla ta'ala. With the exception of Syu'bah al-Khomis, Nawawi al-Bantani did not mention any naql arguments to accompany his sharah. Then in Syu'bah alSadisah, Nawawi al-Bantani only mentions the source of the hadith with the term fi al-șahīh. Whereas in Syu'bah al-Tsaminah, Nawawi alBantani includes two traditions, the first does not mention the source of the hadith, and the second is mentioned. The author searches for the source of the first hadith until it is traced to the book al-Targhib wa al-Tarhïb. (al-Mundziriy, 1424, p. IV/ 291) Meanwhile for the second hadith, Nawawi al-Bantani clearly stated that the hadith he quoted from Șahīh Muslim with the term fi al-ṣahīh Muslim, namely 
Șahīh Muslim no. 2862. (Muslim bin al-Hajjaj, 2010, no. 2862) Broadly speaking, the majority of the hadith quotations cited by Nawawi alBantani in Qami 'al-Tughyan, do not mention the quality of the hadiths quoted. The methods of writing the sources of the hadith quotations in the book Qami 'al-Tughyan are also varied. Most of the traditions in Qami 'al-Tughyan do not include the number of the hadith or the location of the hadith that is quoted (such as the volume and page). Rather, it is merely mentioning the name of the mukharrij, or the name of the book, or even both.

More specifically, the classification of the sources of quotations in Qami 'al-Tughyan can be categorized into three types. First, Nawawi al-Bantani did not mention the literature he quoted. Here the reader must first look for the hadith in question and then do the takhrij in order to know the origin of the hadith (see syu'bah 44). Second, Nawawi al-Bantani said that the quoted hadith was not very clear. For example, only with the sentence fi al-șahīh (see syu'bah 6). Third, Nawawi al-Bantani clearly mentions the quoted hadiths. Namely Nawawi al-Bantani completes the traditions in his syarah with sentences such as fi șahīh al-Bukhāri (see syu'bah 22); fi sunan abi Dawud (see syu'bah 66); fi șahīhaini (see syu'bah 2); rowāhu muslim (see syu'bah 30), etc. Meanwhile, different from the others, there are several sharah passages that do not include quotations from the hadith as a companion to the argument of naql in them. The exclusion of hadith accounts can be classified into at least two domains. First, Nawawi al-Bantani only quoted verses from the al-Quran without citing hadiths. The translation of the verse in question usually uses the term qāla ta'ala (see syu'bah 4) or qāla llahu ta'ala (see syu'bah 32). Second, Nawawi al-Bantani only gave syarah without making receptions of the verses of the al-Quran or hadith (see syu'bah 5 and 31)..

In this case, the variation of Nawawi's recording of the verse and hadith texts (dalail al-naql) shows a straightforward and simple indication. That is, this style is used to lead the reader to directly face the substance of the study being offered, without the need to go 
deeper into the aspects of authenticity of the text. This indication arises from the premise that the historical context of education at that time was still traditional, in which the stimulant of understanding was more dominant and intensive to be conveyed to natives (santri), rather than the problem of literature literature.

In addition, in the discussion of both mind and sharah given, Nawawi inherited a deep cognitive corpus of faith, the characteristics of a servant and its implementation. Especially in the first 10 syu'bah, there are some materials that intensively discuss the theme of the disparity of the characters of "kafir" and "believers" in Islamic discussion (see the offer of syarah Nawawi in the 7th to 1oth syu'bah). Similar themes can be found in other syu'bah, for example 16, 18, 26, 27,28 , etc. This gives an indication that the content delivered by Nawawi is addressed as a critical effort towards social situations that often compromise with opponents (colonial). The various styles, according to the author's opinion, are a treasure trove of struggles that are packaged through the preaching of a work and education for natives.

\section{The Essential Patron from the Work of Nawawi al-Bantani}

Nawawi al-Bantani has advantages and academic virtues in the form of various works originating from the questioner. (Steenbrink, 1980, p. 184) The reasons behind Nawawi al-Bantani in writing a work also vary. In another hadith work, Nawawi al-Bantani wrote specifically a work entitled Tanqih al-Qaul al-Hasis fi Syarh Lubāb alHadis, namely the book of sharah on Lubāb al-Hadis by al-Suyuti (d. $911 \mathrm{H})$. Starting from overcoming the phenomenon of distortion of meaning and editors who have experienced changes in the book; fulfill the desire of the congregation towards teaching hadith; the urge to make the book shyarah because it had never been recited by other scholars (at its time); to the warmth of the conversation about this book among the Javanese people. (al-Bantani, n.d.-b, p. 2) In general, Nawawi al-Bantani shows his highest appreciation for previous scholars by celebrating their work. This was also driven by the motivation to introduce and explain the thoughts of previous scholars. 
(Muqoddas, 2014, p. 14) Besides that, Nawawi also often responds to requests from his colleagues in Java to write several books, this can be found in some of his books preamble.

In addition, Nawawi al-Bantani's background as a Javanese led him to compose this book with an Arabic language style that is easy to understand but with linguistic validity that can still be legitimized. (Maulana \& Astari, 2020, p. 88) Nawawi has the capability to formulate language into a combination of various disciplines in his many works. Nawawi can be said to be a sufi, poet, faqih and other religious titles, judging from his credibility as a figure with deep scientific complexity. In a linguistic review, Nawawi becomes an 'Ajam who has sufficient knowledge in narrating his thoughts in Arabic. (A. Arwansyah \& Shah, 2015, p. 74) There is a lot of evidence found in the text of his work which consists of various verbs, both transitive and intransitive, which are in accordance with the structure and rules of the Arabic language. So that his works, especially Qami 'al-Tughyan, are also used as one of the main literatures in the pesantrenan curriculum. (Mujahadah et al., 2019, p. 95)

It can be analyzed that Nawawi al-Bantani's ability in shyarah can be analyzed that he has special expertise in the characteristics of the syarah that he makes, namely Nawawi al-Bantani is proficient in understanding the text being chanted. So that this ability will lead him to the process of concocting a thorough and in-depth writing pattern. This certainly brings a breath of fresh air for reviewers who want to easily carry out studies or observations of Nawawi's work. Syarah Nawawi al-Bantani's work also describes a broad scientific representation and there is no doubt about his authority as a scholar. (Muqoddas, 2014, p. 14) According to Burhanuddin, the works of Nawawi al-Bantani in almost all scientific fields that he is engaged in have consistency in referring to authoritative sources. (Mamat Slamet Burhanuddin, 2010, p. 128) However, it is found that many of the hadiths quoted in his works have various variants. That is, found many traditions with the status of șahīh, hasan, daif (not accompanied by an explanation of the daif) and hadiths whose source of takhrij is not yet 
known. (Zaenudin, 2019, pp. 85-105) Nawawi al-Bantani most often mentions hadith by relying directly on the Prophet SAW. without mentioning the names of his friends and mukharrij, as in the Kāsyifah al-Saja. (Taqi, 2015, p. 47)

In another of his works, namely Nashaih al-'Ibad, Nawawi alBantani, mentioned some interesting narratives regarding the methodology of writing hadith. First, summarizing the hadiths quoted. Second, describing a hadith in a riwayah bil ma'na. Namely, Nawawi al-Bantani wrote the hadith in his own language and understanding. Third, use certain words in reference to a hadith. The words referred to are akhrajahu, rawāhu, naqāla. Fourth, using certain words in the mention of a hadith. Namely with the words qāla an Prophet SAW, qauluhu an Nabi SAW, ruwiya, fi al-hadis, fi al-khabar. (K. Arwansyah, 2016, p. 47) However, it is not unreasonable, Nawawi al-Bantani uses the argument which can still be accounted for in substance and for the benefit of the people. It is felt that sanad criticism has not been given a priority because it is necessary for the readers to reduce the transmission of the substance of the hadith. In this case, Nawawi al-Bantani thinks that if the traditions which contain aspects of fadāil al-'amāl, it can be tolerated regarding the status that befell him.

In addition, the characteristics of Syarah Nawawi with its various references from the verses of the al-Quran, hadiths, qaul ulama, to Sufi figures. This style seems to lead the reader to a comprehensive deep dive and there is a persuasive invitation to taqarrub ilallah. (Sakinah, n.d., p. 76) According to Steenbrink, the activities of the tarekat in Java, especially Banten, are also rife. He described how the Qadariyah tarekat became a major basis in addition to the Naqsabandiyah order in the room of Sufism with various wirid/ zikr rites practiced by its adherents. (Steenbrink, 1980, p. 55) It cannot be denied that Nawawi al-Bantani was more or less influenced by al-Ghazali $(\mathrm{d} .505 \mathrm{H})$ and asSyafi'i (d. $205 \mathrm{H}$ ) in the jurisprudence and Sufism marriage segment. Both play a role in contributing thoughts that integrate fiqh and Sufism which are often considered to have distortions. (Arsyad, 2017, 
pp. 11-12) This combination was then inscribed by Nawawi in several of his books that had a taste for fiqh and tasawuf. Just say it Nihayah al-Zein, Syarh Sullam al-Munajah, Kāsyifah as-Saja, Salalim alFudhala', Maraqi al-'Ubudiyah, including anyway Qami' al-Tughyan. Especially in the context of a curriculum that is traced through a long historical study, al-Ghazali and as-Syafi'i have a place in the hearts of observers of Islamic scholarship, especially fiqh-tasawuf in Indonesia. So it is not surprising that Nawawi also carries the dominance of both fiqh-tasawuf which is in harmony with the conditions of the nusantara.

The Relationship of Works to the Social Situation of the Nusantara

In terms of social influence and tendencies, Nawawi al-Bantani tends to be influenced by the colonial situation, which at that time practiced imperialism in the nusantara. Nawawi tries to describe this religious interpretation of the practice of colonialism through his presentation in the book Qami 'al-Tughyan. For example, in his presentation of jihad (see syu'bah 26) and murabathah (see syu'bah 27), Nawawi gave an exposition of the responsiveness of a Muslim in dealing with unbelievers. One of the materials that can be learned is the spirit to exert all abilities to fight against infidels and defend territorial demarcation in order to uphold religious independence and nationalism.

In practice, the colonial government considered religious groups like Nawawi to automatically pose a threat to them, because Nawawi and other scholars would certainly intervene in the nusantara to fight injustice with the spirit of Islamic fanaticism. (Michrob \& Mudjahid, 1993, p. 182) Nawawi received psychological support from various elements who rejected colonial atrocities, such as tarekat groups, Islamic boarding schools, the people of Banten and so on. His anxiety with the colonial government, Nawawi was reluctant to cooperate with them or even indigenous people who became colonial sympathizers. (Hidayat, 2019, p. 200) In fact, in reality, Nawawi dared to take action not to be cooperative in establishing cooperative 
relations in any form with the colonialists so that he was not willing to become a leader in Tanara like his father. (Michrob \& Mudjahid, 1993, p. 184)

In another aspect, the colonial side often felt pressure from Nawawi's lectures while in Indonesia. Nawawi's lecture was able to lead the indigenous masses as well as raise awareness to oppose western imperialism. The Dutch colonialist initially only supervised the majlis held by Nawawi, but then a breakdown of communication between the congregation and Nawawi ended in freezing lectures from Nawawi which forced him to leave his homeland. (Bahary, 2015, p. 179) The colonial government's restlessness to discredit Nawawi was due to the fact that the people of Banten at that time greatly honored a haji/ kyai because they had social authority. Given that Nawawi also comes from the lineage of the Sultanate of Banten, this situation has made Nawawi able to attract worshipers to follow him. Until in the end, the chaos in the Banten region, especially in the 18th to 19th centuries, made the social position that was originally relied on to the sultanate, transferred to the hands of the ulama. (Michrob \& Mudjahid, 1993, p. 187)

Actually, Nawawi al-Bantani in his work, Tawsyaikh ibn Qasim alGhuzzi Qut al-Habib al-Gharib, have Istislam principles in the practice of socializing with other parties, including in this case the colonial government. The concept of istislam here is defined as a form of peace and cooperation with anything that is regulated by the authorities/ government, including government that is kafir or nonMuslim, as long as it does not contradict the provisions of the religious law. According to him, this principle is an effort to uphold religion in implementing all the provisions of the Shari'a. (al-Bantani, n.d.-c, p. 255) On the other hand, Nawawi in Qatr al-Ghaits, strictly classifies his da'wah targets into three groups with different hierarchical levels, namely believers, infidels and hypocrites. This is an implication that Nawawi, although he prioritizes the concept of istislam, he still does not validate the parallel with the infidels/ hypocrites who at that time came from colonial and sympathizers. (Fitriana et al., 2016, p. 21) 
Nonetheless, Nawawi al-Bantani is still on the way of his establishment to review on an ongoing basis the political developments in the country. Nawawi continues to contribute ideas for progress, even igniting the spirit of mental awareness to fight injustice, oppression and injustice. This progressive initiative was passed on to students who later contributed to various religious and political movements in the nusantara. (Bruinessen, 1995, p. 52) This polarization of the ideology of independence was also inseparable from the influence of the newness of Islam brought by al-Afghani (d. 1897 AD) and Abduh (d. 1905 AD), who had spread in the Middle East, where most of the graduates were pesantren scholars. Nawawi's resistance gave rise to various assumptions that in fact he was more or less influenced by the phenomenological conditions of the colonial west with all its inherent factors. (A. Arwansyah \& Shah, 2015, p. 8o)

In addition, Nawawi has also conducted various interactive academic seminars. He had been in Egypt to study as well as to attend an invitation from al-Azhar University as a resource person in 1870 . The meetings discussed topics about the written works he had successfully written, as well as topics about the insights of his thoughts. (Dahlan, 1978, p. 85) This is none other than a dialogical and interactive response to follow up on events that occurred and the dynamics of the turbulent thoughts surrounding Nawawi's lifetime, which he then brought to contribute his thoughts in the form of many progressive and modernist works.

\section{Conclusion}

Nawawi al-Bantani al-Jawi is a scholar who has religious credibility and is recognized by making his works as a teaching curriculum for Islamic education. The complexity of his mastery of knowledge by Nawawi al-Bantani encouraged him to write works in a comprehensive range of material, one of which was in Qami' alTughyan. At the level of writing, Nawawi prioritizes the aspects of straightforwardness and simplicity, in which the socialization of understanding is the main substance of this work. Various 
explanations of the arguments and syarah in Qami 'al-Tughyan show a response representation related to the situation of the nusantara, especially those related to the context of struggle and jihad as a form of motivational construction and a foundation against imperialism. In this case, the research on Nawawi al-Bantani and his works deserves to be continued with another multi-paradigm analysis. So that the theological treasure of the nusantara will be preserved in contemporary academic culture.

\section{REFERENCES}

Adeni, A., \& Hasanah, S. 2020. Kontribusi Dakwah Bil Qalam Syaikh Nawawi Al-Bantani terhadap Nasionalisme Pesantren. KOMUNIKA: Jurnal Dakwah Dan Komunikasi, 14(1), 139-154.

al-Bantani, N. n.d.-a. Qami' al-Tughyan 'ala Mandzhumat Syu'ab alIman.

https://drive.google.com/file/d/1EKTFUGyndxiwX2jGZdxp67o EMDzTowq9/edit

al-Bantani, N. n.d.-b. Tanqih al-Qaul al-Hasis fi Syarh Lubab alHadis. Dar al 'Ilm.

al-Bantani, N. n.d.-c. Tawsyaikh ibn Qasim al-Ghuzzi Qut al-Habib al-Gharib. Bengkulu Indah.

al-Bukhari, A. A. M. bin I. 2002. Shahih al-Bukhari. Dar Ibn Katsir.

al-Mundziriy, A. al-A. bin A. al-Qawiy. 1424. Al-Targhib wa al-Tarhib. Maktabah al Ma'arif.

Amin, S. M. 2009. Sayyid Ulama Hijaz: Biografi Syaikh Nawawi alBantani. PT LKiS Pelangi Aksara.

Arsyad, S. 2017. Relasi Fikih dan Tasawuf Dalam Pemikiran Syekh Nawawi Banten. El-Afkar: Jurnal Pemikiran Keislaman Dan Tafsir Hadis, 6(1), 11-18.

Arwansyah, A., \& Shah, F. A. 2015. Peran Syaikh Nawawi Al-Bantani dalam Penyebaran Islam di Nusantara. Kontekstualita: Jurnal Penelitian Sosial Keagamaan, 30(1), 145377.

Arwansyah, K. 2016. Hadith Hadith Daif dan Palsu dalam Nasa'ih al 'Ibad oleh Nawawi Banten: Pengaruhnya terhadap Masyarakat Islam di Sumatera [PhD Thesis]. University of Malaya. 
Bahary, A. 2015. Tafsir Nusantara: Studi Kritis terhadap Marah Labid Nawawi al-Bantani. ULUL ALBAB Jurnal Studi Islam, 16(2), 176-190.

Bizawie, Z. M. 2015. Sanad and Ulama Network of the Quranic Studies in Nusantara. Heritage of Nusantara: International Journal of Religious Literature and Heritage, 4(1), 23-44.

Bruinessen, M. V. 1995. Kitab Kuning. Pesantren dan Tarekat: Tradisi-tradisi Islam di Indonesia. Mizan.

Burhanuddin, Mamat S., Syamsuddin, M., \& Qudsy, S. Z. 2020. Kajian Kontemporer terhadap Karya Nawawi al Bantani. DINIKA: Academic Journal of Islamic Studies, 4(1), 83-102.

Burhanuddin, Mamat Slamet. 2010. KH Nawawi Banten (w. 1314/1897) Akar Tradisi Keintelektualan NU. MIQOT: Jurnal Ilmu-Ilmu Keislaman, 34(1).

Dahlan, C. 1978. Sejarah Pujangga Islam Syekh Nawawi al-Bantani. Jakarta: CV Sarana Utama.

Fitriana, E., Suwirta, A., \& Kamsori, E. 2016. Perjuangan Syeikh Nawawi Al-Bantani Dalam Melawan Kolonialisme di Banten (1831-1897). FACTUM, 5(1), 13-32.

Hamzah, A. 2019. Metode Penelitian Kepustakaan. Malang: Literasi Nusantara.

Hidayah, U. 2014. Aktualisasi Nilai-nilai Kecerdasan Emosional dan Kecerdasan Spiritual: Analisis Kitab Qami’ al Thughyan karya Syaikh Nawawi al Bantani [Masters, Universitas Islam Negeri Maulana Malik Ibrahim]. http://etheses.uinmalang.ac.id/8002/

Hidayat, A. W. 2019. Pemikiran Syekh Nawawi Al-Bantani dan Relevansinya di Era Modern. Aqlam: Journal of Islam and Plurality, 4(2).

Huda, N. 2017. Nilai-nilai Pendidikan Akhlak dalam Kitab Qami'uth Thughyan 'ala Manzhumati Syu'abil Iman Karya Syaikh Muhammad Nawawi al Bantani (1813-1897 M/ 1230-1314 H) [PhD Thesis]. IAIN Salatiga.

Mabrur, M. A. 2016. Pengaruh Karya Syekh Nawawi al-Bantani Dalam Tradisi Kajian Kitab Kuning (Kitab Klasik) di Pesantren Buntet. Jurnal Tamaddun: Jurnal Sejarah Dan Kebudayaan Islam, $1(2)$. 
Maulana, A. A., \& Astari, R. 2020. Verba Transitif dan Intransitif: Analisis Linguistik pada Syair-syair Kutipan Syekh Imam Nawawi al-Bantani dalam Kitab Nas̄ăih al-'Ibād. Maharaat: Jurnal Pendidikan Bahasa Arab, 2(2), 71-89. https://doi.org/10.18196/mht.2218

Michrob, H., \& Mudjahid, C. 1993. Catatan Masa Lalu Banten. PT Saudara.

Mujahadah, A., Sa'dullah, A., \& Dina, L. N. A. B. 2019. Nilai-Nilai Pendidikan Akhlak dalam Kitab Qomi' al-Thughyan. Vicratina: Jurnal Pendidikan Islam, 4(3), 93-103.

Muqoddas, A. 2014. Syeikh Nawawi al Bantani al Jawi Ilmuan Spesialis Ahli Syarah Kitab Kuning. Tarbawi: Jurnal Pendidikan Islam, 11(1).

Muslim bin al-Hajjaj, A. al-Husain. 2010. Shahih Muslim. Dar al Kutub al Ilmiyyah.

Niam, K. 2010. The Discourse of Muslim Intellectuals and Ulama' in Indonesia: A Historical Overview. Journal of Indonesian Islam, 4(2), 287-316.

Rahman, A. 1996. Nawāwī al Bantānī: An Intellectual Master of the Pesantren Tradition. Studia Islamika, 3(3).

Sakinah, F. n.d.. Epistemologi Syarah Hadis Nusantara: Studi Syarah Hadis Tanqih Al Qawl Al Hatsits fi Syarh Lubab Al Hadits Karya Nawawi Al Bantani. Riwayah, 6(1), 71-88.

Siregar, M. 2007. Pemikiran Pendidikan Syekh Nawawi Al Bantani. Yogyakarta: Datamedia.

Steenbrink, K. A. 1980. Beberapa Aspek tentang Islam di Indonesia Abad ke-19. Bulan Bintang.

Taqi, A. Y. 2015. Studi Kritik Hadits Kitab Kasyifah al Saja karya Imam Nawawi al Bantani (Bab Tauhid) [PhD Thesis]. UIN Walisongo.

Zaenudin, Z. 2019. Takhrij Hadis dalam Kitab Tafsīr Marāh Labīd Karya Syaikh Nawawi al Bantani. Holistic Al-Hadis, 5(1), 84107. 